\title{
Feeding dihydroquercetin and vitamin $E$ to broiler chickens reared at standard and high ambient temperatures
}

by Pirgozliev, V., Westbrook, C., Woods, S., Mansbridge, S.C., Rose, P., Whiting, I., Yovchev, D., Atanasov, A., Kljak, K., Staykova, G. and Ivanova, S.

Copyright, publisher and additional information: This is the authors' accepted manuscript. The published version is available via Taylor \& Francis

Please refer to any applicable terms of use of the publisher

DOI link to the version of record on the publisher's site 
1 Feeding dihydroquercetin and vitamin $\mathbf{E}$ to broiler chickens reared at standard and high ambient temperatures

V. Pirgozliev ${ }^{1 a}$, S.C. Mansbridge ${ }^{1}$, C. Westbrook ${ }^{1}$, S. Woods ${ }^{1}$, S.P. Rose ${ }^{1}$, I.M. Whiting ${ }^{1}$, D. Yovchev $^{2}$, A.G. Atanasov ${ }^{3,4,5,6}$, K. Kljak ${ }^{7}$, G.P. Staykova ${ }^{8}$, S. Ivanova ${ }^{9}$, M.R. Karagecili ${ }^{10}$, F. 6 Karadas $^{10}$, J.H. Stringhini ${ }^{11}$

$8 \quad{ }^{1}$ The National Institute of Poultry Husbandry, Harper Adams University, Shropshire, UK

$9 \quad{ }^{2}$ Faculty of Veterinary Medicine, Trakia University, 6000 Stara Zagora, Bulgaria

${ }^{3}$ Ludwig Boltzmann Institute for Digital Health and Patient Safety, Medical University of Vienna, 1090 Vienna, Austria

${ }^{4}$ Institute of Genetics and Animal Biotechnology of the Polish Academy of Sciences, 05-552 Magdalenka, Poland ${ }^{5}$ Institute of Neurobiology, Bulgarian Academy of Sciences, 1113 Sofia, Bulgaria ${ }^{6}$ Department of Pharmacognosy, University of Vienna, 1090 Vienna, Austria

${ }^{7}$ Faculty of Agriculture, University of Zagreb, Croatia

${ }^{8}$ Agricultural Institute, 9700 Shumen, Bulgaria

${ }^{9}$ Agricultural Academy, 1373 Sofia, Bulgaria

${ }^{10}$ Department of Animal Science, Yuzuncu Yil University, Van, Turkey

$20 \quad{ }^{11}$ Universidade Federal de Goias, Goiania, Brazil

${ }^{a}$ Corresponding author: vpirgozliev@ harper-adams.ac.uk

\section{Abstract}

The use of natural antioxidants, in particular polyphenols such as dihydroquercetin (DHQ), in animal nutrition have recently increased in popularity. This may partly be due to the risk of increased incidences of heat stress associated with raising livestock in warmer ambient temperatures, facilitated by global warming, reducing antioxidant capacity. The current research demonstrates the effect of dietary DHQ, vitamin E and standard or high ambient temperatures on growth performance, energy and nutrient metabolism, gastrointestinal tract development (GIT), jejunal villus morphometry and antioxidant status in broiler chickens. Each of the four experimental diets were fed to 16 pens of five birds, which were allocated to four rooms (four pens in each room). The temperature in two rooms was maintained at a constant $35{ }^{\circ} \mathrm{C}$ (high temperature; HT), and the temperature in the other two rooms was gradually reduced from $27{ }^{\circ} \mathrm{C}$ at $7 \mathrm{~d}$ of age to $22{ }^{\circ} \mathrm{C}$ at $20 \mathrm{~d}$ of age (standard temperature; ST). Rearing 
birds at HT reduced: feed intake, weight gain, weight of small intestine, total GIT, liver, spleen, heart, villus height, villus surface area and lowered blood glutationperoxidase (GSH-Px). Dietary DHQ increased blood GSH-Px and total antioxidant status, increased heart weight and reduced caecal size. When fed separately, DHQ and vitamin E improved hepatic vitamin E concentration. Feeding vitamin E increased spleen and liver weights. When fed together, DHQ and vitamin E reduced villus height, villus height to crypt depth ratio and villus surface area. Temperature and antioxidants did not affect energy and nutrient metabolism. There were no effects of dietary antioxidants on growth performance of broiler chickens and there were no mortalities. At present it is unclear if feeding antioxidants (in particular DHQ) at different levels, using different dietary formulations, and rearing birds under a range of environmental conditions may be effective at enhancing production performance and bird health in hot ambient climates.

Key words: broilers, dihydroquercetin (DHQ), vitamin E, growth performance, GSH-Px, ambient temperature

\section{INTRODUCTION}

The rise in temperature due to global warming is an increasingly important consideration for poultry producers to ensure efficient production and good health and welfare of birds (Niu et al., 2009; Quinteiro-Filho et al., 2010). To reduce the impact of high temperatures, producers in hot climates typically use cooling and ventilation systems which increase production costs and are only applicable in intensive production systems (Woods et al., 2020a). However, the use of free-range rearing systems in broiler production is increasing, thus research into different approaches to alleviate the impact of heat stress on bird production performance is needed.

The use of natural antioxidants, in particular polyphenols, in food and nutrition has recently gained increased popularity (Surai, 2014). Dihydroquercetin (DHQ), also known as taxifolin, is a flavonoid, a major sub-group representing plant polyphenols, commonly found in onions, milk thistle, and various conifers (Weidmann, 2012). Dihydroquercetin has been widely applied as an antioxidant for the surface treatment of fresh meat and fish (Kamboh et al., 2019). An extensive review by Fomichev et al. (2017) reported an enhancement in growth performance of poultry and pigs when fed DHQ supplemented diets, with the responses more noticeable during summer months. Pirgozliev et al. (2019a) did not find significant differences in growth performance or physiological variables of fully-grown broilers fed DHQ, when 
reared under industry conditions. It has been suggested, however, that where reported improvements in production variables have been noted in the literature, these may be observed when animals are exposed to heat stress (Fomichev et al. 2017). Rearing animals at temperatures outside their thermal comfort zone may deplete levels of tissue antioxidants; thus, the antioxidant status of animals may be enhanced by dietary DHQ supplementation (Surai, 2014). However, there are no reported studies comparing the response to DHQ of broilers reared under standard and high ambient temperatures. In addition, there are no comparisons between the effectiveness of DHQ and other well recognised antioxidants, e.g. vitamin E, on their impact (and interactions) on growth performance and antioxidant capacity of poultry at different rearing temperatures. Dietary inclusion of supplementary antioxidants, including polyphenols and vitamin E, have been shown to reduce the adverse impact associated with high temperature (reduced antioxidant status and growth performance compared to standard rearing conditions) by improving antioxidant status and growth performance of poultry (Fomichev et al. 2017; Mazur-Kuśnirek et al., 2019).

The primary objectives of this experiment were to study the impact of dietary DHQ and vitamin $\mathrm{E}$ on growth performance variables, dietary $\mathrm{N}$-corrected apparent metabolisable energy (AMEn), dry matter (DMR) and nitrogen retention (NR) coefficients, when fed to broiler chickens from 7 to 28 days of age, reared at industry recommended and high ambient temperatures. In addition, secondary objectives were to examine the impact of experimental diets and ambient temperatures on gastrointestinal tract (GIT) and relative internal organ weights, and jejunal villus morphometry. Finally, an evaluation of the influence of antioxidants and ambient temperatures on bird antioxidant status was determined.

\section{MATERIALS AND METHODS}

\subsection{Experimental diets}

A wheat-soy-based basal grower diet formulated to meet breeder's recommendations (Aviagen Ltd., Edinburgh, UK) (Table 1) was mixed for the experiment. The diet was supplied with 5 $\mathrm{g} / \mathrm{kg}$ of $\mathrm{TiO}_{2}$ as an indigestible marker. The basal diet was then split into four batches that had 1.) no additive (control diet; C); 2.) $\mathrm{C}+0.5 \mathrm{~g} / \mathrm{kg}$ extract of Siberian Larch (Larix sibirica) (JSC NPF Flavit, IBI RAS, Pushchino city, Moscow region, Russian Federation 142290). According to the supplier, this extract contains over $85 \%$ pure DHQ, with the reminder including other flavonoids, saponins and water (DHQ diet); 3.) $\mathrm{C}+0.3 \mathrm{~g} / \mathrm{kg}$ vitamin $\mathrm{E}$ (Merck KGaA, 

$0.3 \mathrm{~g} / \mathrm{kg}$ vitamin $\mathrm{E}$ (DHQ + vit E diet).

\subsection{Animals, husbandry and sample collection}

107 The experiment was conducted at the National Institute of Poultry Husbandry and approved by 108 Harper Adams University Research Ethics Committee, UK. A total of 340 day-old male Ross 109308 broilers were obtained from a commercial hatchery (Cyril Bason Ltd, Craven Arms, UK), 110 allocated to a single floor pen and offered a proprietary wheat-based broiler starter feed 111 formulated to meet Ross 308 nutrient requirements (Aviagen Ltd., Edinburgh, UK). At 7d age, 112320 of the birds, excluding ill and malformed, were allocated at random to the four 113 experimental diets. Each diet was fed to 16 pens (five birds each), 64 pens in total, which were 114 allocated to four rooms (16 pens in each room). Each of the pens had a solid floor and were 115 equipped with an individual feeder and drinker. Feed and water were offered ad libitum to birds throughout the experiment. The temperature in two of the rooms was maintained at a constant $35^{\circ} \mathrm{C}(\mathrm{HT})$, and the temperature in the other two rooms was gradually reduced from $27^{\circ} \mathrm{C}$ at $7 \mathrm{~d}$ age to $22{ }^{\circ} \mathrm{C}$ at $20 \mathrm{~d}$ age (following breeder's recommendations; ST). A standard lighting programme for broilers was used, decreasing the light:dark ratio from $23 \mathrm{~h}: 1 \mathrm{~h}$ from day old to 18h:6h at $7 \mathrm{~d}$ of age, which was maintained until the end of the study. The well-being of the birds was checked regularly every day.

123 Birds and feed were weighed on days 7 and 28 in order to determine average daily feed intake (FI), average daily weight gain (WG) and to calculate the feed conversion ratio (FCR) on a pen basis. For the last three days of the study, from day 18 to day 21, the solid floor of each pen was replaced with a wire mesh. During this period all excreta were collected each day, stored in a fridge $\left(\sim 5^{\circ} \mathrm{C}\right)$, and a well-homogenised representative subsample was dried at $60{ }^{\circ} \mathrm{C}$ and then milled through a $0.75 \mathrm{~mm}$ screen.

130 At the end of the study, one bird per pen (selected at random), was electrically stunned and 131 blood was obtained in heparin coated tubes from the jugular vein. The development of the GIT 132 from the same birds was determined. The proventriculus and gizzard (PG), duodenum, 133 pancreas, jejunum, ileum, caeca, liver, spleen and the heart were immediately collected and 134 weighed. The liver (without gallbladder) was freeze dried and stored at minus $80{ }^{\circ} \mathrm{C}$ before 135 being analysed for vitamin E content. Approximately $5 \mathrm{~cm}$ of the middle part of the jejunum, 
between the point of bile duct entry and Meckel's diverticulum, of one of the birds was sampled and stored in $10 \%$ neutral-buffered formalin.

\subsection{Laboratory Analysis}

140 The analysed chemical composition of the basal diet is detailed in Table 1. Dry matter (DM)

141 in feed and excreta samples was determined by drying of samples in a forced draft oven at 105

$142{ }^{\circ} \mathrm{C}$ to a constant weight (AOAC 2000; method 934.01). Crude protein $(6.25 \times \mathrm{N})$ in samples

143 was determined by the combustion method (AOAC 2000; method 990.03) using a LECO FP-

$144528 \mathrm{~N}$ (Leco Corp., St. Joseph, MI). Oil (as ether extract) in diets was extracted with diethyl

145 ether by the ether extraction method (AOAC 2000; method 945.16) using a Soxtec system

146 (Foss Ltd., Warrington, UK). The gross energy (GE) value of feed and excreta samples was

147 determined in a bomb calorimeter (model 6200; Parr Instrument Co., Moline, IL) with benzoic

148 acid used as the standard. Titanium in feed and excreta was determined as described by Short

149 et al. (1996). Dietary AMEn was calculated following the method of Hill and Anderson (1958),

150 and retention coefficients were determined as previously described (Pirgozliev et al., 2019b).

The glutathione peroxidase (GSH-Px) assay in blood was performed using a Ransel GSH-Px kit (Randox Laboratories Ltd., UK) that employs the method based on that of Paglia and Valentine (1967). Total antioxidant status (TAS) determined in the blood serum was determined using a Randox kit, following manufacturer's recommendations (Randox Laboratories Ltd., UK). The heterophil/lymphocyte (H:L) ratio in blood was determined as described by Müller et al. (2011). The pack cell volume (PCV) test, also called the haematocrit test, was also determined (Fedde and Wideman, 1996). The vitamin E content in diets and livers was determined using an HPLC system as previously described (Karadas et al., 2010, 2014).

The relative empty weights of GIT segments, including spleen and heart, of each bird were determined as previously described (Abdulla et al. 2017; Pirgozliev et al. 2019a). Jejunal samples collected in section 2.2. were embedded in paraffin wax, sectioned at approximately $5 \mu \mathrm{m}$ and four gut segments were fixed on each slide. Morphometric measurements were determined on 20 intact well-oriented villus-crypt units for each bird as previously described

167 (Yovchev et al., 2019). 
170 Data were analysed using Genstat (18 ${ }^{\text {th }}$ edition) statistical software (IACR Rothamstead,

171 Hertfordshire, UK). Comparisons among performance, diet and temperature were performed

172 by a split plot ANOVA procedure using a $2 \times 2 \times 2$ factorial design. The main plots were the

173 four rooms that were each randomly allocated to one of the two temperatures. The pens within

174 each room were the sub-plots and these were randomly allocated to one of the four dietary

175 treatments. The statistical analysis used the following matrix model:

$$
Y_{i j k l}=\mu+A_{i}+N_{l(i)}+B_{j}+C_{k}+(B C)_{j k}+(A B)_{i j}+(A C)_{i k}+(A B C)_{i j k}+\varepsilon_{l(i j k)}
$$

178

179 Where:

$180 \quad \mu_{i}=$ Grand mean

$181 A_{i}=$ Fixed effect of temperature

$182 N_{l(i)}=$ Whole plot (room) error

$183 B_{j}=$ Fixed effect of DHQ

$184 C_{k}=$ Fixed effect of Vit E

$185(B C)_{j k}=$ Fixed interaction of DHQ and Vit E

$186(A B)_{i j}=$ Fixed interaction of temperature and DHQ

$187(A C)_{j k}=$ Fixed interaction of temperature and Vit E

$188(A B C)_{i j k}=$ Fixed three-way interaction of temperature, DHQ and Vit E

$189 \varepsilon_{l(i j k)}=$ Split-plot error

190

191 Data were checked for normal distribution. A protected LSD test was used to separate 192 differences in interaction means if statistical differences were evident $p<0.05$. Means for 193 interactions are only included in tables when p-values were significant.

\section{RESULTS}

196 All birds were healthy throughout the study period and there was no mortality.

\subsection{Growth performance and relative organ weights}

199 The overall bird weight at 28d age was $988 \mathrm{~g}$, with birds reared at ST at $1196 \mathrm{~g}$, and birds 200 reared at HT at $780 \mathrm{~g}(p=0.022)$ (Table 2). Birds at HT had lower FI, (52 vs 81 grams daily; $201 p=0.020)$. Rearing birds at HT reduced their WG from 51 to 30 grams per day $(p=0.028)$. 
The FCR was not affected $(p>0.05)$ by diets or temperature. There was no significant effect of vitamin E or DHQ on bird production performance characteristics.

\section{[Insert Table 2 here]}

206

The information on the GIT of the birds expressed as a relative weight of the body weight is presented in Table 3. Rearing birds at HT reduced the relative weight of jejunum, liver, total GIT, spleen and heart $(p<0.05)$ and also tended $(p=0.091)$ to reduce the weight of the duodenum. Feeding DHQ significantly reduced caecal weight $(p=0.011)$, but increased $(p=$ $0.002)$ relative heart weight. Feeding vitamin $\mathrm{E}$ increased the weight of liver $(p=0.011)$ and spleen $(p=0.009)$ and tended $(p=0.054)$ to increase the relative weight of the PG of the birds. Birds fed vitamin E reared at ST had heavier caeca $(p=0.014)$ compared to birds reared at HT $(0.92 \%$ vs $0.55 \%)$, although no difference $(p>0.05)$ existed in birds fed diets containing no additional vitamin E $(0.77 \%$ vs $0.65 \%)$ for ST and HT respectively.

\section{[Insert Table 3 here]}

\subsection{Dietary AMEn and nutrient availability}

Dietary AMEn, DMR and NR were not significantly influenced by supplementary DHQ, vitamin $\mathrm{E}$ or rearing temperature $(p>0.05)$.

\subsection{Jejunal villus morphometry}

The results of the jejunal villus morphometry of the chicks is presented in Table 4. There were many interactions between the studied treatments. In general, rearing birds at HT reduced VH and villus surface area without any mitigating effect from DHQ or vitamin E. It seems that feeding vitamin E and DHQ together changed the studied villus morphometry variables reducing $\mathrm{VH}, \mathrm{VH}: \mathrm{CD}$ and villus surface area $(p<0.001)$.

[Insert Table 4 here]

\subsection{Antioxidant status of birds}

233 The hepatic vitamin E concentration was not affected by rearing temperature $(\mathrm{P}>0.05)$ (Table

234 5). However, feeding DHQ or vitamin E, improved hepatic vitamin E concentration by $38.6 \%$ and $23 \%$, respectively $(p<0.05)$. The blood GSH-Px of birds reared at HT was $17 \%$ lower $(p$ 
$236=0.039)$ than those of birds reared at ST, i.e. 53 vs $62 \mathrm{U} / \mathrm{ml} \mathrm{RBC}$. However, supplementary

237 DQH increased GSH-Px by $13 \%$ compared to birds fed DHQ free diets $(p=0.013)$, i.e. 61 vs

$23853 \mathrm{U} / \mathrm{ml}$ RBC. Similarly, dietary DHQ improved TAS by $33.3 \%(p=0.021)$ compared to birds

239 fed non-supplemented diets, i.e. 0.81 vs $0.54 \mathrm{mmol} / 1$. The $\mathrm{H}: \mathrm{L}$ ratio was not affected $(p>0.05)$

240 by experimental treatments. There was no diet by rearing temperature interactions $(p>0.05)$

241 for any of the studied variables in Table 5.

[Insert Table 5 here]

\section{DISCUSSION}

246 The aim of this experiment was to evaluate the impact of dietary DHQ and vitamin E, alone and in combination, when fed to broiler chickens reared at high and standard ambient temperatures. The mean average weight of birds reared at the standard temperature at $28 \mathrm{~d}$ of age was $1196 \mathrm{~g}$; which is $27.5 \%$ below the Ross 308 broiler target weight for commercial flocks. The birds were kept in small groups in research facilities, and fed mash diets which were further mixed before feeding, potentially compromising diet homogeneity, thus the reduced performance compared to large commercial flocks was acceptable (Pirgozliev et al., 2016; Yang et al., 2020). It is possible that lighter birds may be less susceptible to heat stress.

\subsection{Growth performance and relative organ weights}

In agreement with previous studies (Quinteiro-Filho et al., 2010), birds reared at a constant temperature of $35^{\circ} \mathrm{C}$ responded with reduced FI and WG, although FCR was not affected by rearing temperature. The results of the relative weights of the organs measured as percentage of body weight agreed with published reports (Abdulla et al. 2016; 2017). Birds in HT group with reduced WG also had a reduced relative weight of the GIT, particularly of the small intestines. Woods et al. (2020a) also found a reduction in the relative weight of the small intestine, liver, spleen and heart in birds reared at HT. A reduction in the relative heart weight of birds reared at HT has previously been observed by Yahav et al. (1999). Changes in relative organ weight may not be related to the reduced feed intake alone, since Palo et al. (1995a) found that restricted feeding only influenced absolute organ weight, not relative organ weight, and changes are transient, resulting in an improved FCR (Palo et al. 1995b). Heat stress can influence hypothalamic peptides involved in appetite regulation (Song et al., 2012) and decrease feed passage rate in the GIT, further decreasing trypsin, chymotrypsin, and amylase activity (Hai et al., 2000). Chronic heat stress can reduce blood supply of the GIT due to 
induced peripheral vasodilation (Mckee et al., 1997), leading to a decreased size of the small intestine and absorptive capacity (Mitchell and Carlisle, 1992). High ambient temperature is therefore likely to reduce weight gain through a variety of mechanisms than the reduced feed intake alone, as noted in this study, though the effects of both factors could not be fully separated.

The enlarged hearts of the birds fed DHQ, coupled with an increase in determined GSH-Px and TAS in this study, infers that there is a potential mechanism of antioxidant protection in birds fed DHQ. However, the enlarged heart of DHQ fed birds is difficult to explain without further pathological and anatomical investigation. Korzeniowska et al. (2019) did not find differences between the relative weight of the spleen in birds fed selenium as an antioxidant. Khan et al. (2010) reported an increase in the relative weight of liver of hens with aflatoxicosis. The same authors (Khan et al., 2010) reported that a concurrent feeding of vitamin E did not ameliorate the toxic effects of aflatoxins in the hens as determined by the relative weight of the liver. Despite the liver and spleen enlargement reported in this study, no lesions and / or discolouration was observed, there was no mortality and no obvious sign of clinical disease. As previously discussed, the pathology was not determined in this study. Thus, an association cannot be made between the increase of organs size and clinical disease in this study.

The lack of response in growth performance variables to DHQ in this study is in accordance with previous research (Pirgozliev et al., 2019a), and is contradictory with the hypothesis that DHQ improves performance of birds reared under stress, i.e. during hot summer time (Fomichev et al., 2017). Published results on the effect of vitamin E on broiler growth performance are inconsistent as the use of vitamin E: improved performance of broilers (Guo et al., 2003); did not influence growth performance of broilers (Goñí et al., 2007; Niu et al., 2009) and has even reduced performance (Bölükbaşi et al., 2006). It would seem that the lack of response is prevalent in the literature and agrees with our findings in this study. However, in this current study, the determined vitamin $\mathrm{E}$ in the control diet was $43.86 \mu \mathrm{g} / \mathrm{g}$ (65.5 IU), which is similar to the levels of dietary vitamin E recommended by the breeder (Aviagen Ltd, Edinburgh, UK) of 65 IU for this age of Ross 308. The similar levels of vitamin E in the diets compared to recommendations suggests a potential explanation for the lack of response observed in growth performance variables in this and other similar studies. 
Despite the reduction in feed intake and changes in GIT segment weights and villus morphometry, the results for AMEn and nutrient retention coefficients in the reported study were not significantly influenced by rearing temperature or dietary antioxidants. There was, however, a $0.9 \mathrm{MJ} / \mathrm{kg}$ difference in AMEn, between HT and ST birds. Birds reared under HT had a similar AMEn value to the expected dietary metabolisable energy (ME), though this does not consider the effect of feed intake. Published data on the impact of high ambient temperature on dietary ME and nutrient digestibility are not consistent. Bonnet et al. (1997) reported a reduction in ME and nutrient digestibility values in birds reared at $35{ }^{\circ} \mathrm{C}$, although Woods et al. (2020a) did not observe differences when studying the same variables at the same temperature. Attia et al. (2018) reported an increase in nutrient digestibility in birds reared at high temperatures, while Koelkebeck et al. (1998) did not find an impact of rearing temperature on amino acid digestibility in laying hens. The differences may be attributed to different age, breed and type of production of the experimental birds, different dietary formulations, exposure to different temperatures for different lengths of time, ambient humidity and rearing conditions. Hai et al. (2000) reported that birds reared at a high temperature had decreased activity of trypsin, chymotrypsin and amylase, and suppressed ability to expel digesta from the crop or small intestine. Reduction in pancreatic enzyme production is usually associated with an increase in the size / weight of the pancreas in order to compensate for the reduced enzyme production (Abdulla et al., 2016). The relative weight of the pancreas in this report was not affected by rearing temperature, suggesting that the reduced release of digesta from the crop to small intestine in HT reared birds may lead to a proportional reduction in the release of pancreatic enzymes. This accounts for the AMEn and nutrient retention coefficients observed. Limited studies have reported comparisons in ME and nutrient availability in antioxidant supplemented diets. In agreement with previous reports (Goñí et al., 2007; Pirgozliev et al., 2019b), no differences were found between the broilers fed control, vitamin E and DHQ with regard to ME and nutrient retention coefficients. Studies with other antioxidants, i.e. dietary selenium, also did not detect differences in ME and nutrient retention coefficients (Choct and Naylor, 2004; Woods et al., 2020b). As ME is a measurement of the available energy in carbohydrates, fats and proteins, it is expected that dietary antioxidants would not greatly impact the ME status.

\subsection{Jejunal villus morphometry}

The results of the villus measurements were in the expected range for birds at this age and reared under similar conditions (Santos et al., 2015; Pirgozliev et al., 2019b). Studying histo- 
morphometric changes in the intestines of broilers during heat stress, Santos et al. (2015) indicated that the duodenum and jejunum showed more damage than the ileum. In agreement

340 with the reported study, Santos et al. (2015) also found that when compared with morphologically normal jejunal villi, the villi of birds reared at HT had decreased height and surface area. The increase in the number and size of the intestinal villi increases the absorption surface per unit of intestinal area (Yovchev et al., 2019), thus, HT reduces the absorptive capacity of the small intestine. However, villus morphometry does not always correlate with detectable differences in bird growth (Pirgozliev et al., 2010) and retention may be considered as a more direct indicator of absorptive capacity.

\subsection{Antioxidant status of birds}

In many cases, the antioxidant status in birds is determined by measuring TAS and GSH-Px activity (Krawczuk-Rybak et al., 2012; Mazur-Kuśnirek et al., 2019). The antioxidant enzyme system, including GSH-Px and TAS, works in concert with free radical scavengers to quench reactive oxygen species and to protect cells from oxidative damage (Surai, 2014). The balance between the production of free radicals and the antioxidant system could be disturbed by heat stress in chickens (Lin et al., 2006). As temperature increases, oxidative stress would be expected to increase and the animal's overall GSH-Px and TAS would be expected to decrease (Sarica et al., 2017). In agreement with these reports, exposing birds to HT in this study decreased the overall GSH-Px and tended to decrease TAS.

Dietary DHQ increased GSH-Px, TAS and hepatic vitamin E which further supports the view that flavonoids can protect animal cells against oxidative stress, an action attributed to their antioxidant properties (Chen and Deuster, 2009). Supplementary vitamin E improved hepatic vitamin E, but did not affect blood antioxidant markers in this study. Feeding vitamin $\mathrm{E}$ with an organic source of selenium to broilers, Choct and Naylor (2004) found changes in blood GSH-Px, but not in the growth performance of the birds. Feeding dietary vitamin E at 200 mg/kg, Mazur-Kuśnirek et al. (2019) observed an improved TAS which was coupled with a higher percentage content of breast muscle. It is known that inadequate vitamin $\mathrm{E}$ status lowers corticosteroid synthesis and thus reduces the animal's ability to cope with stress (Choct and Naylor, 2004). However, the control diet of Mazur-Kuśnirek et al. (2019) showed a very low dosage of vitamin E, $10 \mathrm{mg} / \mathrm{kg}$ vs $40 \mathrm{mg} / \mathrm{kg}$ recommendation (Aviagen Ltd, Edinburgh, 2019), which may explain the observed responses. 
372 The intent was to apply the $\mathrm{H} / \mathrm{L}$ ratio method to measure oxidative stress based on established 373 principles (Maxwell and Robertson, 1998). Heat stress alters homeostasis by affecting the 374 adrenal-corticoid axis and the resulting changes in hormone levels may change the numbers of 375 lymphocyte and heterophil, thus changing the H/L. This method has however been criticised 376 for not providing an adequate indication of stress alone (Müller et al., 2011), which agrees with 377 our results where no significant difference in $\mathrm{H} / \mathrm{L}$ was observed.

379 Broilers selected for an improved feed conversion ratio (e.g. Ross and Cobb strains) were shown to have more difficulty adapting to changes in their environment than in less selected birds (Scheele et al., 1991). The increased PCV in modern broiler strains is associated with an increase in blood viscosity, pulmonary arterial hypertension, ascites and death (Fedde and Wideman, 1996). The PCV values in the reported study were in the expected range (Fedde and Wideman, 1996; Hasan et al., 2015). In agreement with our results, Hasan et al. (2015) also did not find differences in PCV in a study with Cobb 500, despite high rearing temperatures $\left(22{ }^{\circ} \mathrm{C}\right.$ vs $\left.35{ }^{\circ} \mathrm{C}\right)$. It seems that PCV can be changed when birds are exposed to extreme stressors, thus the lack of differences in PCV between birds fed DHQ or vitamin E was not a surprise.

Direct comparisons between studies using DHQ are difficult because there is no consistency in dietary concentrations (Pirgozliev et al., 2019a). In the reported study, DHQ was added at 0.5 $\mathrm{g}$ per $\mathrm{kg}$ feed. On average birds were consuming approximately, $67 \mathrm{~g}$ feed per day, and their average daily weight gain was approximately $41 \mathrm{~g}$. Thus, the average daily consumption of DHQ was $0.03 \mathrm{~g}$ per bird, or $0.73 \mathrm{~g}$ per kilogram daily growth. The lack of adverse effects on animals fed relatively high dietary DHQ concentrations in the reported and in previous studies (Pirgozliev et al., 2019a) gives an opportunity for further research, including various dietary DHQ concentrations. Studying the potential interactions between DHQ and exogenous enzymes, or comparing DHQ of different purities may also be of interest.

400 The mode of action of flavonoids is usually associated with their antioxidant properties (Surai, 401 2014), but flavonoids do not behave the same way in vitro and in vivo (Veskoukis et al. 2012). 402 In the present study, birds fed DHQ or vitamin E had no interaction with rearing temperatures. 403 Thus, the antioxidant properties of DHQ and vitamin E did not benefit the overall growth 404 performance variables of birds reared at high ambient temperature. It should be noted, however, 
that in the reported study, the determined level of dietary vitamin E in the control diet was close to the daily recommendations of the breeder.

407

408

\section{CONCLUSIONS}

409 Rearing birds at a high ambient temperature reduced daily feed intake and weight gain but did

410 not affect the efficiency of feed utilisation. Feeding DHQ or vitamin E improved various

411 aspects of antioxidant status of the birds, although it did not affect growth performance, energy

412 or nutrient availability. There were no observed interactions between dietary antioxidants and

413 rearing temperature in the variables studied. At present it is unclear if feeding antioxidants (in

414 particular DHQ) at different levels may be effective at enhancing production performance and

415 bird health in hot ambient climates.

416

417 ACKNOWLEDGEMENTS

418 Special thanks to Richard James and Rose Crocker of the National Institute of Poultry

419 Husbandry (Harper Adams University) for their technical support in conducting the study.

420

421

\section{DISCLOSURE STATEMENT}

422 The authors report no potential conflicts of interest. This work was not sponsored by any funding agency or commercial company.

\section{DATA AVAILABILITY STATEMENT}

426

The data that support the findings of this study are available from the corresponding author, upon reasonable request, subject to restrictions and conditions.

\section{ETHICS STATEMENT}

430 The authors confirm that they have followed all appropriate EU and UK standards and regulations for the protection of animals used for scientific purposes. All mandatory laboratory health and safety procedures have been complied with in the course of conducting this experimental work. This manuscript complies with the ARRIVE guidelines (Kilkenny et al., 2010).

437 VR Pirgozliev - https://orcid.org/0000-0002-4213-7609 
SP Rose - https://orcid.org/0000-0001-6459-597X

$440 \quad$ S Ivanova - https://orcid.org/0000-0002-6226-1287

441 AG Atanasov - https://orcid.org/0000-0003-2545-0967

442 F Karadas - https://orcid.org/0000-0002-8187-349X

443 Jose Henrique Stringhini - https://orcid.org/0000-0002-3710-6963

444

445 REFERENCES

446 Abdulla, J., Rose, S. P., Mackenzie, A. M., Mirza, M. W. and Pirgozliev, V. 2016. Exogenous 447 tannase improves feeding value of a diet containing field beans (Vicia faba) when fed to 448 broilers. British Poultry Science, 57, pp. 246 - 250. DOI:10.1080/00071668.2016.1143551.

Abdulla, J., Rose, S.P. and Mackenzie, A.M., and Pirgozliev, V. 2017. Feeding value of field beans (Vicia faba L. var. minor) with and without enzyme containing tannase, pectinase and xylanase activities for broilers. Archives of Animal Nutrition 71, pp. 150 - 164. DOI: 10.1080/1745039X.2017.1283823.

454

455

AOAC. 2000. Official Methods of Analysis of the Association of Agricultural Chemists. $17^{\text {th }}$ 456 ed. Washington, DC: Association of Official Analytical Chemists.

457

Attia, Y.A., Al-Harthi, M.A. and Sh. Elnaggar, A. 2018. Productive, physiological and immunological responses of two broiler strains fed different dietary regimens and exposed to

460 heat stress. Italian Journal of Animal Science, 17(3), pp. 686 - 697. DOI: 461 10.1080/1828051X.2017.1416961.

462

463

Bölükbaşi, Ş.C., Erhan, M.K. and Özkan, A. 2006. Effect of dietary thyme oil and vitamin E

464 on growth, lipid oxidation, meat fatty acid composition. South African Journal of Animal 465 Science, 36(3), pp. $189-196$.

466

467 Bonnet, S., Geraert, P.A., Lessire, M., Carre, B. and Guillaumin, S., 1997. Effect of high 468 ambient temperature on feed digestibility in broilers. Poultry Science, 76(6), pp. 857 - 863. 469 DOI: $10.1093 / \mathrm{ps} / 76.6 .857$. 
471

472

473

474

475

476

477

478

479

480

481

482

483

484

485

486

487

488

489

490

491

492

493

494

495

496

497

498

499

500

501

502

Chen, Y. and Deuster, P. 2009. Comparison of quercetin and dihydroquercetin: Antioxidantindependent actions on erythrocyte and platelet membrane. Chemico-biological interactions, 182(1), pp. 7 - 12. DOI: 10.1016/j.cbi.2009.06.007.

Choct, M. and Naylor, A.J. 2004. The effect of dietary selenium source and vitamin E levels on performance of male broilers. Asian-Australasian Journal of Animal Sciences, 17(7), pp. 1000 - 1006. DOI: 10.5713/ajas.2004.1000.

Fedde, M.R. and Wideman Jr, R.F. 1996. Blood viscosity in broilers: influence on pulmonary hypertension syndrome. Poultry Science, 75(10), pp. 1261 - 1267. DOI: 10.3382/ps.0751261.

Fomichev, U.P., L.A Nikanova, V.I. Dorozhkin, A.A. Torshkov, A.A. Romanenko, E.K. Eskov, A.A. Semenova, V.A. Gonockij, A.V. Dunaev, G.S. Jaroszewicz, S.A. Lashin, N.I. Stol'naja 2017. Dihydroquercetin (Taxifolin) and Arabinogalactan- natural bioregulators in human and animals, using in agricultural and food industry monography. Scientific Library, ISBN 978-5-6040214-7-7.

Goñí, I., Brenes, A., Centeno, C., Viveros, A., Saura-Calixto, F., Rebole, A., Arija, I. and Estevez, R. 2007. Effect of dietary grape pomace and vitamin E on growth performance, nutrient digestibility, and susceptibility to meat lipid oxidation in chickens. Poultry Science, 86(3), pp. 508 - 516. DOI: 10.1093/ps/86.3.508.

Guo, Y., Zhang, G., Yuan, J. and Nie, W. 2003. Effects of source and level of magnesium and vitamin $\mathrm{E}$ on prevention of hepatic peroxidation and oxidative deterioration of broiler meat. Animal Feed Science and Technology, 107(1-4), pp. 143 - 150. DOI: 10.1016/S03778401(03)00116-0.

Hai, L., Rong, D. and Zhang, Z.Y. 2000. The effect of thermal environment on the digestion of broilers. Journal of Animal Physiology and Animal Nutrition, 83(2), pp. 57 - 64. DOI: 10.1046/j.1439-0396.2000.00223.x.

Hasan, S., Hossain, M.M., Alam, J. and Bhuiyan, M.E.R. 2015. Beneficial effects of probiotic on growth performance and hemato-biochemical parameters in broilers during heat stress. International Journal of Innovation and Applied Studies, 10(1), p. 244 - 249. 
506 Hill, F. W., and D. L. Anderson. 1958. Comparison of metabolisable energy and productive

Kamboh, A.A., Leghari, R.A., Khan, M.A., Kaka, U., Naseer, M., Sazili, A.Q. and Malhi, K.K. 2019. Flavonoids supplementation-An ideal approach to improve quality of poultry products. World's Poultry Science Journal, 75(1), pp. 115 - 126. DOI: 10.1017/S0043933918000703.

512

513 Karadas, F., V. Pirgozliev, A. C. Pappas, T. Acamovic, and M. R. Bedford. 2010. Effects of

514 different dietary phytase activities on the concentration of antioxidants in the liver of growing 515 broilers. Journal of Animal Physiology and Animal Nutrition 94: 519-526. DOI: 10.1111/j.1439-0396.2009.00938.x.

518 Karadas, F., V. Pirgozliev, S. P. Rose, D. Dimitrov, O. Oduguwa, and D. Bravo. 2014. Dietary essential oils improve the hepatic anti-oxidative status of broiler chickens. British Poultry Science, 55, pp. 329 - 334. DOI:10.1080/00071668.2014.891098.

Khan, W.A., Khan, M.Z., Khan, A. and Hussain, I. 2010. Pathological effects of aflatoxin and their amelioration by vitamin E in White Leghorn layers. Pakistan Veterinary Journal, 30(3), pp. $155-162$.

525

Kilkenny, C., Browne, W.J., Cuthill, I.C., Emerson, M. and Altman, D.G. 2010. Improving bioscience research reporting: the ARRIVE guidelines for reporting animal research. PLoS biology, 8(6). DOI: doi:10.1371/journal.pbio.1000412.

Koelkebeck, K.W., Parsons, C.M. and Wang, X. 1998. Effect of acute heat stress on amino acid digestibility in laying hens. Poultry Science, 77(9), pp. 1393 - 1396. DOI: 10.1093/ps/77.9.1393.

533

534 Korzeniowska, M., Madej, J.P., Stefaniak, T. and Kopec, W. 2019. Influence of Selenium on the Morphology of Immune System Organs in Healthy Broilers. Acta Veterinaria, 69(4), pp. 379 - 390. DOI: 10.2478/acve-2019-0032. 
538 Krawczuk-Rybak, M., Panasiuk, A., Czygier, M., Muszynska-Roslan, K., Wysocka, J. and 539 Szmitkowski, M. 2012. Total antioxidant status (TAS) in childhood cancer survivors. Folia 540 Histochemica et Cytobiologica, 50(3), pp. 468 - 472. DOI: 10.5603/FHC.2012.0065.

542 Lin, H., Decuypere, E. and Buyse, J. 2006. Acute heat stress induces oxidative stress in broiler 543 chickens. Comparative Biochemistry and Physiology Part A: Molecular \& Integrative 544 Physiology, 144(1), pp. 11 - 17. DOI: 10.1016/j.cbpa.2006.01.032.

Maxwell, M.H. and Robertson, G.W. 1998. The avian heterophil leucocyte: a review. World's Poultry Science Journal, 54(2), pp. 155 - 178. DOI: 10.1079/WPS19980012.

Mckee, J., Harrison, P. and Riskowskim, G. 1997. Effects of supplemental ascorbic acid on the energy conversion of broiler chicks during heat stress and feed withdrawal. Poultry Science, 76, pp. 1278 - 1286. DOI: 10.1093/ps/76.9.1278.

552

Mazur-Kuśnirek, M., Antoszkiewicz, Z., Lipiński, K., Kaliniewicz, J., Kotlarczyk, S. and 554 Żukowski, P. 2019. The effect of polyphenols and vitamin E on the antioxidant status and meat quality of broiler chickens exposed to high temperature. Archives of Animal Nutrition, 73(2), pp. 111 - 126. DOI: 10.1080/1745039X.2019.1572342.

557

Mitchell, M.A. and Carlisle, A.J. 1992. The effects of chronic exposure to elevated environmental temperature on intestinal morphology and nutrient absorption in the domestic fowl (Gallus domesticus). Comparative Biochemistry and physiology. A, Comparative Physiology, 101(1), pp.137-142. DOI: 10.1016/0300-9629(92)90641-3.

562

Müller, C., Jenni-Eiermann, S. and Jenni, L. 2011. Heterophils/Lymphocytes-ratio and circulating corticosterone do not indicate the same stress imposed on Eurasian kestrel nestlings. Functional Ecology, 25(3), pp. 566 - 576. DOI: 10.1111/j.1365-2435.2010.01816.x.

Niu, Z.Y., Liu, F.Z., Yan, Q.L. and Li, W.C., 2009. Effects of different levels of vitamin E on growth performance and immune responses of broilers under heat stress. Poultry Science, 88(10), pp.2101-2107. DOI: 10.3382/ps.2009-00220. 
571 Paglia, D.E., and Valentine, W.N. 1967. Studies on the quantitative and qualitative characterization of erythrocyte glutathione peroxidase. The Journal of Laboratory and Clinical MedicineI, 70, pp. 158 - 169. DOI: 10.5555/uri:pii:0022214367900765.

Palo, P.E., Sell, J.L., Piquer, F.J., Soto-Salanova, M.F. and Vilaseca, L. 1995a. Effect of Early

Nutrient Restriction on Broiler Chickens.: 1. Performance and Development of the

Gastrointestinal Tract. Poultry Science, 74(1), pp. 88 - 101. DOI: 10.3382/ps.0740088.

578

579

580

581

582

583

584

585

586

587

588

589

590

591

592

593

594

595

596

597

598

599

600

601

602

603

604

Palo, P.E., Sell, J.L., Piquer, F.J., Vilaseca, L. and Soto-Salanova, M.F. 1995b. Effect of early nutrient restriction on broiler chickens. 2. Performance and digestive enzyme activities. Poultry Science, 74(9), pp. 1470 - 1483. DOI: 10.3382/ps.0741470.

Pirgozliev, V., Mansbridge, S.C., Rose, S.P., Mackenzie, A.M., Beccaccia, A., Karadas, F., Ivanova, S.G., Staykova, G.P., Oluwatosin, O.O. and Bravo, D. 2019a. Dietary essential oils improve feed efficiency and hepatic antioxidant content of broiler chickens. animal, 13(3), pp. 502 - 508. DOI: 10.1017/S1751731118001520.

Pirgozliev, V., Westbrook, C., Woods, S., Karagecili, M.R., Karadas, F., Rose, S.P. and Mansbridge, S.C. 2019b. Feeding dihydroquercetin to broiler chickens. British Poultry Science, 60(3), pp. 241 - 245. DOI: 10.1080/00071668.2018.1556387.

Pirgozliev, V.R., Rose, S.P. and Bedford, M.R. 2010. The effect of amylose-amylopectin ratio in dietary starch on growth performance and gut morphology in broiler chickens. Archiv fur Geflugelkunde, 74, pp. S21 - S29.

Pirgozliev, V., Mirza, M.W. and Rose, S.P. 2016. Does the effect of pelleting depend on the wheat sample when fed to chickens? animal, 10(4), pp. 571 - 577. DOI: $10.1017 / S 1751731115002311$.

Quinteiro-Filho, W.M., Ribeiro, A., Ferraz-de-Paula, V., Pinheiro, M.L., Sakai, M., Sá, L.R.M.D., Ferreira, A.J.P. and Palermo-Neto, J. 2010. Heat stress impairs performance parameters, induces intestinal injury, and decreases macrophage activity in broiler chickens. Poultry Science, 89(9), pp. 1905 - 1914. DOI: 10.3382/ps.2010-00812. 
605 Santos, R.R., Awati, A., Roubos-van den Hil, P.J., Tersteeg-Zijderveld, M.H., Koolmees, P.A. 606 and Fink-Gremmels, J. 2015. Quantitative histo-morphometric analysis of heat-stress-related 607 damage in the small intestines of broiler chickens. Avian Pathology, 44(1), pp. 19 - 22. DOI: $608 \quad 10.1080 / 03079457.2014 .988122$.

609

610 Sarıca, S., Aydın, H. and Ciftci, G. 2017. Effects of dietary supplementation of some 611 antioxidants on liver antioxidant status and plasma biochemistry parameters of heat-stressed 612 quail. Turkish Journal of Agriculture-Food Science and Technology, 5(7), pp. 773 - 779. DOI: 613 10.24925/turjaf.v5i7.773-779.1182.

614

615 Scheele, C.W., De Wit, W., Frankenhuis, M.T. and Vereijken, P.F.G. 1991. Ascites in 616 Broilers.: 1. Experimental Factors Evoking Symptoms Related to Ascites. Poultry Science, 617 70(5), pp. 1069 - 1083. DOI: 10.3382/ps.0701069.

618

619 Short, F.J., P. Gorton, J. Wiseman, J. and K.N. Boorman. 1996. Determination of titanium 620 dioxide added as an inert marker in chicken digestibility studies. Animal Feed Science and 621 Technology, 59, pp. 215 - 221. DOI: 10.1016/0377-8401(95)00916-7.

622

623 Song, Z., Liu, L., Sheikhahmadi, A., Jiao, H. and Lin, H. 2012. Effect of heat exposure on gene 624 expression of feed intake regulatory peptides in laying hens. BioMed Research International. 625 DOI: $10.1155 / 2012 / 484869$.

626

627

Surai, P.F. 2014. Polyphenol compounds in the chicken/animal diet: from the past to the future. Journal of Animal Physiology and Animal NutritionI, 98, pp. 19 - 31. DOI: 10.1111/jpn.12070.

630 Veskoukis, A. S., A. Kyparos, M.G. Nikolaidis, D. Stagos, N. Aligiannis, M. Halabalaki, K. 631 Chronis, N. Goutzourelas, L. Skaltsounis, and D. Kouretas. 2012. The antioxidant effects of a 632 polyphenolrich grape pomace extract in vitro do not correspond in vivo using exercise as an 633 oxidant stimulus. Oxidative Medicine and Cellular Longevity. DOI: 10.1155/2012/185867.

634

635 Weidmann, A.E. 2012. Dihydroquercetin: more than just an impurity? European Journal of 636 Pharmacology 684, pp. 19 - 26. DOI: 10.1016/j.ejphar.2012.03.035. 
638 Woods, S. L., Rose, S. P., Whiting, I. M., Blanchard, A., Ionescu, C. and Pirgozliev, V. 2020a.

639 The effect of saturated and non-saturated fat on growth performance, dietary apparent 640 metabolisable energy and nutrient retention when fed to broiler chickens at two different 641 temperatures, British Poultry Abstracts.

642

643 Woods, S.L., Sobolewska, S., Rose, S.P., Whiting, I.M., Blanchard, A., Ionescu, C., Bravo, D. 644 and Pirgozliev, V. 2020b. Effect of feeding different sources of selenium on growth 645 performance and antioxidant status of broilers. British Poultry Science. DOI: $64610.1080 / 00071668.2020 .1716301$.

647

648 Yahav, S. 1999. Effect of early-age thermal conditioning and food restriction on performance 649 and thermotolerance of male broiler chickens. British Poultry Science, 40(1), pp. 120 - 126. 650 DOI: 10.1080/00071669987944.

651

652 Yang, Z., Pirgozliev, V.R., Rose, S.P., Woods, S., Yang, H.M., Wang, Z.Y. and Bedford, M.R. 653 2020. Effect of age on the relationship between metabolizable energy and digestible energy for 654 broiler chickens. Poultry Science, 99(1), pp. 320 - 330. DOI: 10.3382/ps/pez495.

655

656 Yovchev, D., Penchev, G., Dimitrov, D. and Stamatova-Yovcheva, K. 2019. 657 Micromorphometric study of the small intestines in different post-hatch periods in bronze 658 turkey (Meleagris meleagris gallopavo). Bulgarian Journal of Agricultural Science, 25(3), pp. $659552-557$.

660 
Table 1. Ingredient composition [ $\mathrm{g} / \mathrm{kg}$ 'as fed'] and nutritional analysis of the basal diet for broiler chickens

\begin{tabular}{|c|c|}
\hline Ingredients & $\mathrm{g} / \mathrm{kg}$ \\
\hline Wheat & 550 \\
\hline Soya bean meal [crude protein $=48 \%$ ] & 230 \\
\hline Barley & 79 \\
\hline Full fat soya meal & 50 \\
\hline Soya oil & 45 \\
\hline Limestone & 12.5 \\
\hline Monocalcium phosphate & 12.5 \\
\hline Salt & 2.5 \\
\hline Sodium bicarbonate & 1.5 \\
\hline L Lysine HCL & 3 \\
\hline DL Methionine & 3.5 \\
\hline L Threonine & 1.5 \\
\hline Vitamin/Mineral premix* & 4 \\
\hline Titanium dioxide & 5 \\
\hline Total & 1000 \\
\hline \multicolumn{2}{|l|}{ Calculated values [as fed] } \\
\hline Crude protein [Nx6.25] & 201 \\
\hline Crude fat $[\mathrm{g} / \mathrm{kg}]$ & 68 \\
\hline Metabolisable energy $[\mathrm{MJ} / \mathrm{kg}]$ & 12.99 \\
\hline Calcium $[\mathrm{g} / \mathrm{kg}]$ & 9.3 \\
\hline Available Phosphorus $[\mathrm{g} / \mathrm{kg}]$ & 4.2 \\
\hline Available Lysine $[\mathrm{g} / \mathrm{kg}]$ & 11.8 \\
\hline Methionine + Cysteine $[\mathrm{g} / \mathrm{kg}]$ & 9.4 \\
\hline \multicolumn{2}{|l|}{ Determined values } \\
\hline Dry matter & 894 \\
\hline Gross energy [MJ/kg] & 17.43 \\
\hline Crude protein [N x 6.25] & 194 \\
\hline Crude fat $[\mathrm{g} / \mathrm{kg}]$ & 69 \\
\hline Vitamin $\mathrm{E}[\mu \mathrm{g} / \mathrm{g}]^{\dagger}$ & 43.86 \\
\hline \multicolumn{2}{|c|}{$\begin{array}{l}\text { *The vitamin and mineral premix contained vitamins and trace elements to meet the } \\
\text { requirements specified by NRC [1994] except vitamin E. There was no vitamin E } \\
\text { supplemented to the control diet. The premix provided [units/kg feed]: retinol } 3600 \mu \mathrm{g} \text {, } \\
\text { cholecalciferol } 125 \mu \mathrm{g} \text {, menadione } 3 \mathrm{mg} \text {, thiamine } 2 \mathrm{mg} \text {, riboflavin } 7 \mathrm{mg} \text {, pyridoxine } 5 \mathrm{mg} \text {, } \\
\text { cobalamin } 15 \mu \mathrm{g} \text {, nicotinic acid } 50 \mathrm{mg} \text {, pantothenic acid } 15 \mathrm{mg} \text {, folic acid } 1 \mathrm{mg} \text {, biotin } 200 \mu \mathrm{g} \text {, } \\
\text { iron } 80 \mathrm{mg} \text {, copper } 10 \mathrm{mg} \text {, manganese } 100 \mathrm{mg} \text {, cobalt } 0.5 \mathrm{mg} \text {, zinc } 80 \mathrm{mg} \text {, iodine } 1 \mathrm{mg} \text {, } \\
\text { selenium } 0.2 \mathrm{mg} \text { and molybdenium } 0.5 \mathrm{mg} \text {. }\end{array}$} \\
\hline
\end{tabular}


674 Table 2. Effect of bird rearing temperature $\left[\mathrm{T}^{\circ} \mathrm{C}\right]$, dietary dihydroquercetin [DHQ] and vitamin

$675 \mathrm{E}$ [Vit E] on bird final body weight [BW], bird daily feed intake [FI], bird daily weight gain

676 [WG], feed conversion ratio [FCR], N-corrected apparent metabolisable energy [AMEn], dry

677 matter [DMR] and nitrogen [NR] retention coefficients, when fed to broiler chickens from 7 to

$67828 \mathrm{~d}$ age *

\begin{tabular}{|c|c|c|c|c|c|c|c|c|}
\hline & Initial BW [g] & BW 28d [g] & FI [g/d] & WG [g/d] & FCR & $\begin{array}{l}\text { AMEn } \\
{[\mathrm{MJ} / \mathrm{kg}]^{\dagger}}\end{array}$ & $\mathrm{DMR}^{\dagger}$ & $\mathrm{NR}^{\dagger}$ \\
\hline \multicolumn{9}{|l|}{$\mathrm{T}^{\circ} \mathrm{C}$} \\
\hline $\mathrm{ST}^{*}$ & 119 & 1196 & 81 & 51 & 1.589 & 11.74 & 0.703 & 0.659 \\
\hline $\mathrm{HT}^{\#}$ & 123 & 780 & 52 & 30 & 1.683 & 12.64 & 0.743 & 0.650 \\
\hline $\mathrm{SEM}^{\S}$ & 2.2 & 44.0 & 2.9 & 2.6 & 0.0295 & 0.324 & 0.0152 & 0.0078 \\
\hline \multicolumn{9}{|l|}{ DHQ } \\
\hline No & 122 & 987 & 66 & 41 & 1.631 & 12.15 & 0.719 & 0.651 \\
\hline Yes & 121 & 990 & 67 & 40 & 1.640 & 12.24 & 0.728 & 0.658 \\
\hline SEM $^{\S}$ & 0.6 & 17.5 & 0.9 & 1.0 & 0.0183 & 0.083 & 0.0050 & 0.0059 \\
\hline \multicolumn{9}{|l|}{ Vit E } \\
\hline No & 121 & 1001 & 67 & 41 & 1.629 & 12.16 & 0.721 & 0.652 \\
\hline Yes & 121 & 975 & 66 & 40 & 1.642 & 12.22 & 0.726 & 0.657 \\
\hline $\mathrm{SEM}^{\S}$ & 0.6 & 17.5 & 0.9 & 1.0 & 0.0183 & 0.083 & 0.0050 & 0.0059 \\
\hline \multicolumn{9}{|l|}{$p$-Values } \\
\hline $\mathrm{T}^{\circ} \mathrm{C}$ & 0.112 & 0.022 & 0.020 & 0.028 & 0.152 & 0.189 & 0.201 & 0.481 \\
\hline DHQ & 0.242 & 0.903 & 0.881 & 0.723 & 0.727 & 0.427 & 0.209 & 0.384 \\
\hline Vit E & 0.677 & 0.300 & 0.259 & 0.479 & 0.612 & 0.604 & 0.471 & 0.574 \\
\hline $\mathrm{T}^{\circ} \mathrm{C} \times \mathrm{DHQ}$ & 0.469 & 0.723 & 0.499 & 0.448 & 0.854 & 0.903 & 0.965 & 0.979 \\
\hline $\mathrm{SEM}^{\S}$ & 2.2 & 47.3 & 3.1 & 2.8 & 0.0347 & 0.335 & 0.0160 & 0.0098 \\
\hline $\mathrm{T}^{\circ} \mathrm{C} \times$ Vit $\mathrm{E}$ & 0.609 & 0.068 & 0.086 & 0.095 & 0.429 & 0.224 & 0.379 & 0.313 \\
\hline $\mathrm{SEM}^{\S}$ & 2.2 & 47.3 & 3.1 & 2.8 & 0.0347 & 0.335 & 0.0160 & 0.0098 \\
\hline DHQ x Vit E & 0.544 & 0.974 & 0.274 & 0.899 & 0.096 & 0.261 & 0.257 & 0.587 \\
\hline $\mathrm{SEM}^{\S}$ & 0.8 & 24.7 & 1.3 & 1.4 & 0.0259 & 0.118 & 0.0070 & 0.0084 \\
\hline $\mathrm{T}^{\circ} \mathrm{C} \times \mathrm{DHQ} \times \mathrm{Vit} \mathrm{E}$ & 0.222 & 0.996 & 0.843 & 0.890 & 0.350 & 0.330 & 0.361 & 0.899 \\
\hline $\mathrm{SEM}^{\S}$ & 2.4 & 53.4 & 3.3 & 3.1 & 0.0433 & 0.355 & 0.0175 & 0.0129 \\
\hline
\end{tabular}

$679 *$ Each mean average represents values from thirty two replicate pens for main effects; ${ }^{\dagger} \mathrm{AMEn}$,

680 DMR and NR were determined between 25 and 28 days of age; ${ }^{\star} \mathrm{ST}=$ the ambient temperature

681 was gradually reduced from $27^{\circ} \mathrm{C}$ at $7 \mathrm{~d}$ age to $22^{\circ} \mathrm{C}$ at $20 \mathrm{~d}$ age; ${ }^{*} \mathrm{HT}=$ high rearing temperature

682 of constant $35{ }^{\circ} \mathrm{C} ;{ }^{\S} \mathrm{SEM}=$ pooled standard errors of mean.

683

684 
685 Table 3. Effect of bird rearing temperature $\left[\mathrm{T}^{\circ} \mathrm{C}\right]$, dietary dihydroquercetin [DHQ] and vitamin E [Vit E] on the relative organ weight expressed 686 as the percent of body weight [BW] of gastrointestinal tract, liver, spleen and heart of $28 \mathrm{~d}$ old broiler chickens*

\begin{tabular}{|c|c|c|c|c|c|c|c|c|c|c|c|}
\hline & $\mathrm{BW}$ & $\mathrm{PG}$ & Duodenum & Pancreas & Jejunum & Ileum & Caeca & GIT & Liver & Spleen & Heart \\
\hline \multicolumn{12}{|l|}{$\mathrm{T}^{\circ} \mathrm{C}$} \\
\hline $\mathrm{ST}^{*}$ & 1231 & 2.42 & 1.06 & 0.30 & 1.91 & 1.52 & 0.85 & 8.05 & 2.31 & 0.08 & 0.71 \\
\hline $\mathrm{HT}^{\#}$ & 779 & 2.48 & 0.90 & 0.31 & 1.45 & 1.27 & 0.60 & 7.01 & 1.77 & 0.05 & 0.47 \\
\hline $\mathrm{SEM}^{\S}$ & 45.2 & 0.057 & 0.035 & 0.012 & 0.043 & 0.105 & 0.049 & 0.110 & 0.030 & 0.001 & 0.035 \\
\hline \multicolumn{12}{|l|}{ DHQ } \\
\hline No & 1011 & 2.41 & 0.96 & 0.31 & 1.67 & 1.43 & 0.78 & 7.57 & 2.03 & 0.07 & 0.56 \\
\hline Yes & 1000 & 2.49 & 1.0 & 0.30 & 1.69 & 1.34 & 0.66 & 7.49 & 2.05 & 0.08 & 0.61 \\
\hline SEM $^{\S}$ & 21.5 & 0.051 & 0.027 & 0.010 & 0.055 & 0.050 & 0.034 & 0.144 & 0.036 & 0.003 & 0.010 \\
\hline \multicolumn{12}{|l|}{ Vit E } \\
\hline No & 996 & 2.38 & 0.95 & 0.30 & 1.70 & 1.38 & 0.71 & 7.43 & 1.97 & 0.06 & 0.60 \\
\hline Yes & 1015 & 2.52 & 1.01 & 0.31 & 1.66 & 1.41 & 0.73 & 7.63 & 2.11 & 0.07 & 0.58 \\
\hline SEM $^{\S}$ & 21.5 & 0.051 & 0.027 & 0.010 & 0.055 & 0.050 & 0.034 & 0.144 & 0.036 & 0.003 & 0.010 \\
\hline \multicolumn{12}{|l|}{$p$-Values } \\
\hline $\mathrm{T}^{\circ} \mathrm{C}$ & - & 0.552 & 0.091 & 0.654 & 0.018 & 0.231 & 0.071 & 0.022 & 0.006 & 0.001 & 0.040 \\
\hline DHQ & - & 0.214 & 0.354 & 0.887 & 0.845 & 0.188 & 0.011 & 0.689 & 0.695 & 0.873 & 0.002 \\
\hline Vit E & - & 0.054 & 0.165 & 0.580 & 0.570 & 0.717 & 0.678 & 0.322 & 0.011 & 0.009 & 0.257 \\
\hline $\mathrm{T}^{\circ} \mathrm{C} \times \mathrm{DHQ}$ & - & 0.147 & 0.625 & 0.300 & 0.604 & 0.528 & 0.387 & 0.777 & 0.262 & 0.791 & 0.187 \\
\hline SEM $^{\S}$ & & 0.076 & 0.044 & 0.016 & 0.070 & 0.012 & 0.060 & 0.181 & 0.047 & 0.003 & 0.037 \\
\hline $\mathrm{T}^{\circ} \mathrm{C} \times \mathrm{Vit} \mathrm{E}$ & - & 0.627 & 0.741 & 0.376 & 0.636 & 0.900 & $0.014^{\dagger}$ & 0.750 & 0.428 & 0.556 & 0.787 \\
\hline $\mathrm{SEM}^{\S}$ & & 0.076 & 0.044 & 0.016 & 0.070 & 0.012 & 0.060 & 0.181 & 0.047 & 0.003 & 0.037 \\
\hline DHQ x Vit E & - & 0.136 & 0.683 & 0.182 & 0.923 & 0.465 & 0.823 & 0.350 & 0.797 & 0.319 & 0.264 \\
\hline $\mathrm{SEM}^{\S}$ & & 0.072 & 0.038 & 0.014 & 0.077 & 0.071 & 0.048 & 0.204 & 0.050 & 0.004 & 0.014 \\
\hline $\mathrm{T}^{\circ} \mathrm{C} \times$ DHQ $\times$ Vit $\mathrm{E}$ & & 0.969 & 0.898 & 0.228 & 0.832 & 0.311 & 0.814 & 0.734 & 0.609 & 0.744 & 0.654 \\
\hline $\mathrm{SEM}^{\S}$ & & 0.104 & 0.058 & 0.021 & 0.104 & 0.136 & 0.077 & 0.273 & 0.069 & 0.006 & 0.039 \\
\hline
\end{tabular}

687 *Each mean average represents values from thirty two replicate pens for main effects; ${ }^{\ddagger} \mathrm{ST}=$ the ambient temperature was gradually reduced from

$68827{ }^{\circ} \mathrm{C}$ at $7 \mathrm{~d}$ age to $22{ }^{\circ} \mathrm{C}$ at $20 \mathrm{~d}$ age; ${ }^{\#} \mathrm{HT}=$ high rearing temperature of constant $35{ }^{\circ} \mathrm{C} ;{ }^{\circledR} \mathrm{SEM}=$ pooled standard errors of mean; ${ }^{\dagger}$ Birds fed vitamin

689 E reared at ST had heavier caeca [ $p=0.014]$ compared to birds reared at HT [0.92 vs 0.55], although no difference [ $p>0.05]$ existed in birds fed

690 diets containing no additional vitamin E [0.77 vs 0.65] for ST and HT respectively. 
692 Table 4. Effect of bird rearing temperature $\left[\mathrm{T}^{\circ} \mathrm{C}\right]$, dietary dihydroquercetin [DHQ] and vitamin 693 E [Vit E] on the villus height [VH], villus width [VW], crypt depth [CD] and villus surface 694 area [Area] of 28d old broiler chickens*.

695

\begin{tabular}{|c|c|c|c|c|c|c|c|}
\hline & & & $\begin{array}{l}\mathrm{VH} \\
{[\mu \mathrm{m}]}\end{array}$ & $\begin{array}{l}\mathrm{VW} \\
{[\mu \mathrm{m}]}\end{array}$ & $\begin{array}{l}\mathrm{CD} \\
{[\mu \mathrm{m}]}\end{array}$ & VH:CD & Area $\left(\mathrm{mm}^{2}\right)$ \\
\hline \multicolumn{8}{|l|}{$\mathrm{T}^{\circ} \mathrm{C}$} \\
\hline $\mathrm{ST}^{*}$ & & & 1300 & 172 & 336 & 4.0 & 0.706 \\
\hline $\mathrm{HT}^{\#}$ & & & 856 & 155 & 167 & 5.2 & 0.413 \\
\hline $\mathrm{SEM}^{\S}$ & & & 2.8 & 0.4 & 0.2 & 0.01 & 0.0015 \\
\hline \multicolumn{8}{|l|}{ DHQ } \\
\hline No & & & 1136 & 169 & 227 & 5.2 & 0.601 \\
\hline Yes & & & 1020 & 158 & 276 & 4.0 & 0.517 \\
\hline $\mathrm{SEM}^{\S}$ & & & 2.4 & 1.6 & 1.3 & 0.04 & 0.0067 \\
\hline \multicolumn{8}{|l|}{ Vit E } \\
\hline No & & & 1081 & 166 & 229 & 4.9 & 0.565 \\
\hline Yes & & & 1076 & 161 & 274 & 4.3 & 0.553 \\
\hline $\mathrm{SEM}^{\S}$ & & & 2.4 & 1.6 & 1.3 & 0.04 & 0.0067 \\
\hline $\mathrm{T}^{\circ} \mathrm{C}$ & DHQ & & & & & & \\
\hline ST & No & & 1408 & 171 & 300 & $4.7^{\mathrm{a}}$ & 0.758 \\
\hline $\mathrm{ST}$ & Yes & & 1193 & 173 & 371 & $3.3^{\mathrm{b}}$ & 0.653 \\
\hline HT & No & & 865 & 167 & 153 & $5.6^{\mathrm{c}}$ & 0.445 \\
\hline HT & Yes & & 847 & 143 & 182 & $4.7^{\mathrm{a}}$ & 0.381 \\
\hline SEM $^{\S}$ & & & 3.7 & 1.7 & 1.3 & 0.04 & 0.0069 \\
\hline $\mathrm{T}^{\circ} \mathrm{C}$ & Vit E & & & & & & \\
\hline ST & No & & 1363 & 169 & 305 & $4.6^{\mathrm{b}}$ & 0.725 \\
\hline ST & Yes & & 1237 & 174 & 367 & $3.4^{\mathrm{c}}$ & 0.687 \\
\hline HT & No & & 799 & 164 & 153 & $5.3^{\mathrm{a}}$ & 0.406 \\
\hline HT & Yes & & 914 & 147 & 182 & $5.1^{\mathrm{a}}$ & 0.420 \\
\hline SEM $^{\S}$ & & & 3.7 & 1.7 & 1.3 & 0.04 & 0.0069 \\
\hline DHQ & Vit E & & & & & & \\
\hline No & No & & 1035 & 173 & 198 & $5.3^{\mathrm{a}}$ & 0.545 \\
\hline No & Yes & & 1238 & 165 & 256 & $5.1^{\mathrm{a}}$ & 0.658 \\
\hline Yes & No & & 1127 & 160 & 260 & $4.5^{\mathrm{b}}$ & 0.585 \\
\hline Yes & Yes & & 913 & 156 & 293 & $3.4^{\mathrm{c}}$ & 0.449 \\
\hline SEM $^{\S}$ & & & 3.5 & 2.3 & 1.9 & 0.05 & 0.0095 \\
\hline $\mathrm{T}^{\circ} \mathrm{C}$ & DHQ & Vit E & & & & & \\
\hline ST & No & No & $1326^{\mathrm{d}}$ & $155^{\mathrm{a}}$ & $260^{\mathrm{a}}$ & 5.1 & $0.647^{\mathrm{b}}$ \\
\hline ST & No & Yes & $1489^{g}$ & $186^{\mathrm{c}}$ & $341^{\mathrm{c}}$ & 4.4 & $0.869^{f}$ \\
\hline ST & Yes & No & $1400^{\mathrm{e}}$ & $183^{\mathrm{c}}$ & $350^{\mathrm{d}}$ & 4.0 & $0.803^{\mathrm{e}}$ \\
\hline ST & Yes & Yes & $985^{\mathrm{a}}$ & $163^{\mathrm{ab}}$ & $393^{f}$ & 2.5 & $0.504^{\mathrm{a}}$ \\
\hline HT & No & No & $744^{\mathrm{b}}$ & $190^{\mathrm{d}}$ & $135^{\mathrm{b}}$ & 5.5 & $0.443^{\mathrm{d}}$ \\
\hline HT & No & Yes & $987^{\mathrm{f}}$ & $144^{\mathrm{ab}}$ & $171^{\mathrm{c}}$ & 5.8 & $0.446^{\mathrm{d}}$ \\
\hline HT & Yes & No & $854^{c}$ & $138^{\mathrm{a}}$ & $171^{\mathrm{c}}$ & 5.0 & $0.368^{\mathrm{bc}}$ \\
\hline HT & Yes & Yes & $841^{\mathrm{c}}$ & $149^{\mathrm{b}}$ & $192^{\mathrm{e}}$ & 4.4 & $0.394^{\mathrm{c}}$ \\
\hline $\mathrm{SEM}^{\S}$ & & & 5.1 & 2.8 & 2.3 & 0.06 & 0.0117 \\
\hline \multicolumn{8}{|l|}{$p$-Values } \\
\hline $\mathrm{T}^{\circ} \mathrm{C}$ & & & $<0.001$ & 0.001 & $<0.001$ & $<0.001$ & $<0.001$ \\
\hline DHQ & & & $<0.001$ & $<0.001$ & $<0.001$ & $<0.001$ & $<0.001$ \\
\hline Vit E & & & 0.133 & 0.015 & $<0.001$ & $<0.001$ & 0.219 \\
\hline $\mathrm{T}^{\circ} \mathrm{C} \times \mathrm{DHQ}$ & & & $<0.001$ & $<0.001$ & $<0.001$ & $<0.001$ & 0.034 \\
\hline $\mathrm{T}^{\circ} \mathrm{C} \times$ Vit E & & & $<0.001$ & $<0.001$ & $<0.001$ & $<0.001$ & 0.008 \\
\hline DHQ x Vit E & & & $<0.001$ & 0.443 & $<0.001$ & $<0.001$ & $<0.001$ \\
\hline $\mathrm{T}^{\circ} \mathrm{C} \times \mathrm{DHQ} \times \mathrm{Vit} \mathrm{E}$ & & & $<0.001$ & $<0.001$ & $<0.001$ & 0.305 & $<0.001$ \\
\hline
\end{tabular}

696 *Each mean average represents values from thirty two replicate pens for main effects; ${ }^{\star} \mathrm{ST}=$ 697 the ambient temperature was gradually reduced from $27{ }^{\circ} \mathrm{C}$ at $7 \mathrm{~d}$ age to $22{ }^{\circ} \mathrm{C}$ at $20 \mathrm{~d}$ age; ${ }^{\#} \mathrm{HT}$ $698=$ high rearing temperature of constant $35^{\circ} \mathrm{C} ;{ }^{\S} \mathrm{SEM}=$ pooled standard errors of mean.

$699{ }^{a-c}$ Values within a column not sharing the same superscripts differ significantly at $p \leq 0.05$. 
700 Table 5. Effect of bird rearing temperature $\left[\mathrm{T}^{\circ} \mathrm{C}\right]$, dietary dihydroquercetin [DHQ] and vitamin $701 \mathrm{E}$ [Vit E] on hepatic vitamin E, blood plasma glutathione peroxidase [GSH-Px], total 702 antioxidant status [TAS], blood heterophil to lymphocyte [H:L] ratio and packed cell volume $703 \quad[\mathrm{PCV}]$ in $28 \mathrm{~d}$ old broiler chickens*.

\begin{tabular}{|c|c|c|c|c|c|}
\hline & $\begin{array}{l}\text { Hepatic vitamin E } \\
{[\mu \mathrm{g} / \mathrm{g}]}\end{array}$ & $\begin{array}{l}\text { GSH-Px } \\
{[\mathrm{U} / \mathrm{ml} \mathrm{RBC]}}\end{array}$ & $\begin{array}{l}\text { TAS } \\
{[\mathrm{mmol} / \mathrm{l}]}\end{array}$ & $\mathrm{H}: \mathrm{L}$ & PCV \\
\hline \multicolumn{6}{|l|}{$\mathrm{T}^{\circ} \mathrm{C}$} \\
\hline $\mathrm{ST}^{\sharp}$ & 52 & 62 & 0.72 & 1.09 & 31.8 \\
\hline $\mathrm{HT}^{\#}$ & 84 & 53 & 0.63 & 1.22 & 26.0 \\
\hline SEM $^{\S}$ & 11.5 & 1.3 & 0.103 & 0.111 & 1.45 \\
\hline \multicolumn{6}{|l|}{ DHQ } \\
\hline No & 57 & 53 & 0.54 & 1.11 & 29.3 \\
\hline Yes & 79 & 61 & 0.81 & 1.20 & 28.5 \\
\hline $\mathrm{SEM}^{\S}$ & 4.8 & 2.3 & 0.078 & 0.063 & 0.57 \\
\hline \multicolumn{6}{|l|}{ Vit E } \\
\hline No & 61 & 57 & 0.74 & 1.13 & 29.1 \\
\hline Yes & 75 & 57 & 0.61 & 1.17 & 28.7 \\
\hline $\mathrm{SEM}^{\S}$ & 4.8 & 2.3 & 0.078 & 0.063 & 0.57 \\
\hline \multicolumn{6}{|l|}{$p$-Values } \\
\hline $\mathrm{T}^{\circ} \mathrm{C}$ & 0.185 & 0.039 & 0.606 & 0.485 & 0.107 \\
\hline DHQ & 0.002 & 0.013 & 0.021 & 0.298 & 0.315 \\
\hline Vit E & 0.043 & 0.964 & 0.219 & 0.655 & 0.643 \\
\hline $\mathrm{T}^{\circ} \mathrm{C} \times \mathrm{DHQ}$ & 0.858 & 0.094 & 0.819 & 0.470 & 0.388 \\
\hline $\mathrm{SEM}^{\S}$ & 12.4 & 2.6 & 0.129 & 0.128 & 1.56 \\
\hline $\mathrm{T}^{\circ} \mathrm{C} \mathrm{x}$ Vit E & 0.061 & 0.248 & 0.223 & 0.778 & 0.869 \\
\hline $\mathrm{SEM}^{\S}$ & 12.4 & 2.6 & 0.129 & 0.128 & 1.56 \\
\hline DHQ x Vit E & 0.575 & 0.603 & 0.084 & 0.829 & 0.716 \\
\hline $\mathrm{SEM}^{\S}$ & 6.8 & 3.3 & 0.110 & 0.089 & 0.80 \\
\hline $\mathrm{T}^{\circ} \mathrm{C} \times \mathrm{DHQ} \times \mathrm{Vit} \mathrm{E}$ & 0.634 & 0.102 & 0.746 & 0.190 & 0.914 \\
\hline $\mathrm{SEM}^{\S}$ & 14.2 & 4.2 & 0.169 & 0.156 & 1.75 \\
\hline
\end{tabular}

704 *Each mean average represents values from thirty two replicate pens for main effects; ${ }^{\dagger} \mathrm{ST}=$ 705 the ambient temperature was gradually reduced from $27{ }^{\circ} \mathrm{C}$ at $7 \mathrm{~d}$ age to $22{ }^{\circ} \mathrm{C}$ at $20 \mathrm{~d}$ age; ${ }^{\#} \mathrm{HT}$ $706=$ high rearing temperature of constant $35^{\circ} \mathrm{C} ;{ }^{\S} \mathrm{SEM}=$ pooled standard errors of mean. 